\title{
MODEL PENJADWALAN PADA BATCH PROCESSOR TUNGGAL DENGAN WAKTU PROSES YANG TIDAK KONSTAN UNTUK MEMINIMASI TOTAL WAKTU TINGGAL AKTUAL
}

\section{A SCHEDULING MODEL FOR A SINGLE BATCH PROCESSOR WITH UNFIXED PROCESSING TIME TO MINIMIZE TOTAL ACTUAL FLOW TIME}

\author{
${ }^{1}$ Murni Dwi Astuti, ${ }^{2}$ Abdul Hakim Halim \\ 1.Program Studi Teknik Industri, Fakultas Rekayasa Industri, Telkom University \\ ${ }^{2}$ Program Studi Teknik Industri, Fakultas Teknologi Industri, Institut Teknologi Bandung \\ 1'murnidwiastuti@telkomuniversity.ac.id, ${ }^{2}$ ahakimhalim@1spitb.org
}

\begin{abstract}
Abstrak - Penjadwalan batch sudah didiskusikan di beberapa penelitian. Terdapat dua jenis penjadwalan batch yaitu job processor dan batch processor. Pada job processor, part diproses secara bergantian sampai semua part dalam satu batch selesai diproses, sedangkan pada batch processor part diproses bersama dalam satu waktu sehingga waktu untuk memproses batch besarnya sama dengan waktu untuk memproses satu part. Berbeda dengan penelitian sebelumnya, pada penelitian ini waktu untuk memproses batch bukan hanya waktu untuk memproses satu part namun gabungan dari waktu yang diperlukan untuk memproses satu part dan waktu untuk memasang tools pada setiap part dalam satu batch. Penelitian ini merupakan tahap ke dua, setelah sebelumnya dikembangkan model yang sama namun untuk masalah single item dengan due date yang sama maka pada penelitian ini due date dari item berbeda - beda Model penjadwalan untuk masalah multi due date diselesaikan dengan menganggap satu interval waktu yang merupakan selisih antar dua due date yang berurutan sebagai masalah common due date. Jumlah minimum batch yang terbentuk untuk setiap interval waktu ini adalah satu dan waktu minimal untuk memproses batch besarnya sama dengan waktu untuk memproses satu part ditambah dengan waktu yang diperlukan untuk memasang tools untuk seluruh part pada satu batch. Jika waktu pada interval waktu tidak cukup untuk memproses part yang diminta pada interval waktu tersebut maka part diproses pada interval waktu setelahnya. Model diuji dengan beberapa set data hipotetik. Variabel keputusan adalah jumlah batch dan ukuran batch untuk setiap interval waktu, dan urutan pengerjaan batch sehingga akan meminimasi total waktu tinggal aktual.
\end{abstract}

Kata kunci: batch, batch processor, single item, common due date, multi due date, waktu tinggal aktual

\footnotetext{
Abstract - Batch scheduling has been discussed in several studies. There are two types of batch scheduling, job processor and batch processor. On job processor, parts are processed alternately until all parts are processed, while in batch processor parts in batch are processed together in one time. Hence the processing time for
}

batches is equal to one part processing time. Unlike the previous study, in this study batch processing time not only time to process one part but it is the sum of processing time of one part and time to install tools on each part in one batch. This paper is continuation of previously developed batch scheduling model for single item common due date problem, hence for multi due date.The scheduling model for single item multi due date is solved by considering one time interval which is the difference between two successive due dates as a common due date issue. The minimum number of batches generated for each time interval is one and the minimum time required to process this batch is the one-part processing time plus the time required to install tools on all parts in one batch. If the time at the time interval is not sufficient to process the requested part at that time interval then the part is processed at the time interval thereafter. The resulting model was tested using several sets of hypothetical data. The decision variables in this scheduling model are the number of batches and batch size for each batch at each time interval, and the order of batch work so as to minimize the total actual flow time.

Keywords: batch, batch processor, single item, commondue date, multi due date, actual flow time

\section{PENDAHULUAN}

Sukoyo dkk [1] menguraikan penjadwalan batch. Karakteristik permasalahan yang diselesaikan dengan penjadwalan batch tidak sama dengan penjadwalan job. Untuk penjadwalan batch, job yang akan dikerjakan dibagi ke dalam beberapa kelompok. Kelompok - kelompok ini disebut sebagai batch, sehingga jumlah job yang akan dikerjakan berubah menjadi jumlah batch dan waktu yang diperlukan untuk memproses job ini sangat tergantung kepada bagaimana batch dibentuk. Hal ini menyebabkan permasalahan penjadwalan menjadi tidak sederhana karena masalah yang harus diselesaikan tidak hanya menjadwalkan pengerjaan 
batch saja namun juga harus ditentukan bagaimana membagi job yang ada ke dalam batch, menentukan berapa ukuran dari batch yang terbentuk, dan menentukan urutan pemrosesan batch yang sudah dibentuk.

Penjadwalan batch dilakukan karena adanya pertimbangan efisiensi [2]. Dengan menerapkan penjadwalan batch, pemrosesan job dapat dilakukan lebih efisien dibanding memproses job secara bergantian dan saat pemrosesan job satu dengan job yang lain dibutuhkan waktu untuk set up. Kegiatan set up ini diperlukan untuk mengubah peralatan yang digunakan maupun membersihkan mesin yang digunakan.

Dalam industri manufaktur, penjadwalan batch merupakan sistem yang sangat banyak diaplikasikan [3]. Dengan dilakukanya penjadwalan batch akan menghindari set up . Jenis batch terdiri dari dua yaitu batch serial dan batch paralel. Batch serial, merupakan batch dengan kondisi job yang berada pada satu batch adalah job dengan set up yang sama dan job diproses secara bergantian sampai seluruh job yang ada dalam satu batch selesai diproses. Batch paralel, adalah batch dengan kondisi beberapa job digabungkan menjadi satu batch dengan memperhatikan batasan kapasitas mesin dan job yang berada pada satu batch diproses bersamasama pada satu waktu. Pada saat part dalam batch mulai diproses, mesin tidak dapat diberhentikan sampai mesin selesai memproses part dalam batch. Pada istilah penjadwalan yang sering digunakan. sistem batch serial sering disebut sebagai job processor dan sistem batch parallel sering disebut dengan batch processor.

Batch merupakan sekumpulan part yang diproses dengan set up yang sama [4]. Batch yang dihasilkan dari sejumlah part yang diminta dapat dikerjakan menggunakan job processor dan batch processor. Pada job processor, part dalam batch diproses secara bergantian, sehingga waktu yang dibutuhkan untuk memproses seluruh part yang terdapat dalam satu batch adalah waktu untuk memproses satu part dikalikan dengan jumlah part yang berada pada satu batch. Pada batch processor, part yang terdapat pada satu batch diproses secara bersamaan, sehingga waktu yang dibutuhkan untuk memproses seluruh part dalam batch nilainya sama dengan waktu untuk memproses satu part.

Masalah penjadwalan batch yang paling sederhana adalah penjadwalan batch pada mesin tunggal. Penelitian yang telah dilakukan untuk masalah penjadwalan batch pada mesin tunggal diantaranya Halim dkk [5], Dobson dan Nambimadom [6], Sukoyo dkk [7], Hidayat dkk [4], dan Astuti dkk [8]. Halim dkk [5] mengusulkan model untuk menyelesaikan permasalahan penjadwalan batch pada job processor untuk single item dengan due date yang berbeda - beda (multi due date) yang akan meminimasi total waktu tinggal aktual. Waktu yang diperlukan untuk memproses part dalam batch adalah tQ dengan $\mathrm{t}$ adalah waktu yang dibutuhkan untuk memproses satu part dan Q merupakan jumlah part yang berada pada satu batch. Dobson dan Nambimadom [6] membahas penjadwalan batch untuk kasus multi item dengan sistem batch berupa batch processor yang meminimasi total weighted flow time. Pada penelitian ini seluruh job diasumsikan siap pada saat $\mathrm{t}=0 . \mathrm{Job}$ berasal dari famili yang berbeda- beda sehingga waktu proses antar famili berbeda. Kriteria pengelompokan job ke dalam satu batch adalah kesamaan waktu proses sehingga job yang hanya berasal dari famili sejenis yang diproses dalam satu batch. Sukoyo dkk [7] mengusulkan model untuk memecahkan penjadwalan batch yang diproses menggunakan job processor dengan waktu proses yang nilainya mengalami kenaikan. Kenaikan ini disebabkan oleh urutan pengerjaan batch. Hidayat dkk [4] mengusulkan model untuk memecahkan penjadwalan batch yang diproses menggunakan batch processor untuk single item. Waktu proses untuk memproses seluruh part dalam batch adalah konstan yang besarnya sama dengan waktu yang diperlukan untuk memproses satu part. Astuti dkk [8] mengusulkan model untuk penjadwalan batch yang diproses dengan menggunakan batch processor tunggal untuk masalah single item dengan due date yang sama (common due date) dengan waktu proses yang tidak konstan agar total waktu tinggal aktual minimal.

Pada penelitian ini diusulkan model penjadwalan batch yang merupakan pengembangan dari model pada penelitian penelitian sebelumnya. Model yang diusulkan untuk menyelesaikan permasalahan penjadwalan batch yang diproses menggunakan batch processor untuk single item dengan due date yang berbeda - beda dengan waktu proses yang tidak konstan agar total waktu tinggal aktual minimal. Pengembangan yang dilakukan dari penelitian sebelumnya adalah pada waktu proses batch yang tidak konstan karena pemasangan tools pada setiap part dalam batch yang akan diproses dan pada due date yang berbeda- beda.

\section{STUDILITERATUR}

Waktu tinggal aktual merupakan lamanya suatu job berada di lantai produksi dari saat job mulai diproses sampai saat job tersebut dikirim pada due date nya [9]. Jika terdapat sejumlah job (n) yang diminta pada due date yag sama(d) dengan waktu proses job adalah p, saat mulai pemrosesan job $\mathrm{i}$ adalah $\mathrm{Bi}$, dan waktu set up mesin adalah s dan diasumsikan besarnya waktu set up tidak dipengaruhi oleh urutan pemrosesan job, sehingga waktu tinggal aktual diberikan oleh persamaan:

$$
\mathrm{F}_{\mathrm{i}}^{\mathrm{a}}=\mathrm{d}-\mathrm{B}_{\mathrm{i},} \quad \text { untuk } \mathrm{i}=1,2, . . \mathrm{n}
$$

Dengan menggunakan pendekatan penjadwalan mundur maka persamaan (1) dapat ditulis menjadi:

$F_{i}^{a}=\sum_{j=1}^{i}\left(p_{j}+s_{j}\right)-s_{i} \quad$ untuk $i=1,2, . . n$

Persamaan (2) merupakan formulasi untuk menentukan waktu tinggal aktual job. Waktu tinggal aktual batch dihitung melalui cara seperti pada persamaan (2), namun untuk waktu proses dikalikan dengan jumlah part yang terdapat pada satu batch, sehingga didapatkan waktu tinggal aktual untuk batch adalah:

$F_{i}^{a}=\sum_{j=1}^{i}\left(t_{j} Q_{[j]}+S_{j}\right)-S_{i}$ 
Dengan $t_{j}$ adalah waktu proses untuk setiap part dalam batch, $\mathrm{Q}_{[\mathrm{j}]}$ adalah jumlah part yang berada pada satu batch dan $\mathrm{s}_{i}$ adalah waktu yang diperlukan untuk kegiatan set up sebelum batch diproses. Persamaan (3) digunakan untuk menentukan waktu tinggal aktual untuk batch yang diproses pada job processor dimana job yang terdapat pada satu batch diproses secara bergantian. Pada batch processor, menggunakan sistem yang berbeda dengan job processor. Pada batch processor, seluruh part yang terdapat pada satu batch diproses secara bersamaan sehingga waktu yang dibutuhkan untuk memproses batch besarnya sama dengan waktu untuk memproses satu part [4]. Dengan demikian waktu tinggal aktual seluruh batch pada batch processor adalah:

$F S^{\alpha}=\sum_{i=1}^{N}\left\{\sum_{j=1}^{i}\left(t_{j}+s_{j}\right)\right\}-s_{i}$

Persamaan (4) digunakan untuk menentukan total waktu tinggal aktual untuk total part pada total batch dengan waktu proses t dan waktu set up batch $\mathrm{s}$.

Permasalahan penjadwalan batch yang diproses pada batch processor dengan besarnya waktu proses tidak konstan karena adanya aktivitas memasang tools pada part dalam batch sebelum diproses pada mesin. Dengan demikian, waktu yang dibutuhkan untu memproses batch merupakan penjumlahan dari waktu untuk memproses satu part dan waktu untuk memsaang tools untuk setiap part dalam satu batch. Total waktu tinggal aktual untuk permasalahan ini dirumuskan sebagai berikut:

$\mathrm{F}^{\mathrm{a}}=\sum_{i=1}^{N}\left\{\sum_{j=1}^{i}\left(\left(t_{j}+a Q_{[j]}\right)+s_{j}\right)-s_{i}\right\}$

$\mathrm{t}_{\mathrm{j}}$ menyatakan waktu proses batch processor, a menyatakan waktu untuk memasang tools pada setiap part dalam batch, $\mathrm{Q}_{[\mathrm{j}]}$ menyatakan jumlah part pada satu batch, dan $\mathrm{s}_{\mathrm{i}}$ menyatakan waktu set up batch.

\section{METODOLOGI PENELITIAN}

Model penjadwalan batch untuk single item multi due date merupakan pengembangan dari model single item common due date. Pada permasalahan common due date semua part yang selesai dikerjakan dikirim pada waktu (due date) yang sama. Pada permasalahan multi due date pengiriman part yang selesai dikerjakan dilakukan pada saat yang berbeda - beda sesuai dengan due date dari masing masing part. Pada penjadwalan multi due date, penjadwalan memperhatikan due date dari part sehingga pada permasalahan ini tidak diperbolehkan mengirimkan part melebihi due date yang diminta.

Misalkan terdapat $\mathrm{n}_{1}, \mathrm{n}_{2}, \ldots, \mathrm{n}_{\mathrm{r}}$ part yang merupakan item sejenis (single item) yang akan diproses pada batch processor tunggal dengan due date masing - masing part adalah $\mathrm{d}_{1}$, $\mathrm{d}_{2, \ldots}, \mathrm{d}_{\mathrm{r}}$. Waktu proses untuk setiap part adalah sama (t) dan pengelompokan part ke dalam batch berdasarkan due date dari masing- masing part. Batch processor yang digunakan untuk memproses part membutuhkan waktu set up (s) pada setiap pemrosesan batch. Lamanya waktu set up untuk setiap batch tidak tergantung kepada banyaknya part yang akan diproses dalam setiap batch. Proses set up ini dilakukan sebelum kedatangan part di lantai produksi. Ketika part akan diproses pada batch processor, pada setiap part dipasang tools. Waktu yang dibutuhkan untuk memasang tools diasumsikan sama untuk setiap part (a). Pemasangan tools dilakukan saat part sudah siap di lantai produksi sehingga akan mempengaruhi waktu untuk memproses batch. Waktu untuk memproses batch menjadi waktu proses pada batch processor dan waktu untuk pemasangan tools pada setiap part untuk satu batch. Permasalahan disini adalah bagaimana mengelompokkan sejumlah part $\left(\mathrm{n}_{\mathrm{h}}\right)$ untuk $\mathrm{h}=1,2, \ldots, \mathrm{r}$ ke dalam batch dan bagaimana menjadwalkan batch yang dihasilkan agar dapat memenuhi due date dari masing-masing part dengan waktu tinggal aktual seluruh part pada lantai produksi $\left(\mathrm{F}^{\mathrm{a}}\right)$ adalah minimal.

Pada penelitian ini didapatkan model matematika untuk penjadwalan batch untuk single item multi due date untuk meminimasi total waktu tinggal aktual. Dengan menggunakan notasi:

a Waktu pemasangan tools pada part yang nilainya diasumsikan konstan (unit waktu/ unit)

b urutan interval waktu

$\mathrm{B}_{\mathrm{h}[\mathrm{i}]}$ Waktu mulai batch pada interval $\mathrm{H}_{\mathrm{h}}$ pada posisi ke- $\mathrm{i}$

$\mathrm{d}_{\mathrm{b}} \quad$ Due date ke-h $(\mathrm{h}=1,2,3, \ldots, \mathrm{r})$ yang dihitung dari posisi terakhir pada skala waktu (multi due date)

$\mathrm{D}_{\mathrm{h}} \quad$ Jumlah part yang diproses pada periode $\mathrm{H}_{\mathrm{h}}$

$\mathrm{F}^{\mathrm{a}} \quad$ Total waktu tinggal aktual part di lantai produksi

$\mathrm{h}$ Indeks untuk mengidentifikasi interval waktu, diantara dua due date yang berdekatan, dalam periode penjadwalan, $\mathrm{h}=1, \ldots, \mathrm{r} . \mathrm{h}$ dihitung dari posisi terakhir pada rentang waktu

$\mathrm{H}_{\mathrm{h}} \quad$ Periode waktu yang didefinisikan sebagai:

$\mathrm{H}_{\mathrm{h}}= \begin{cases}\mathrm{d}_{\mathrm{h}}-\mathrm{d}_{\mathrm{h}+1}-\mathrm{S}_{\mathrm{k}}, \mathrm{h}=1_{s .}(\mathrm{r}-1) \\ \mathrm{d}_{\mathrm{h},}, \mathrm{h}=\mathrm{r}\end{cases}$

i Indeks yang menunjukkan posisi batch, dihitung dari posisi terakhir pada skala waktu dari batch pada jadwal produksi. $\mathrm{i} \neq \mathrm{j}$

j Indeks yang menunjukkan posisi batch, dihitung dari posisi terakhir pada skala waktu dari batch pada jadwal produksi. $\mathrm{i} \neq \mathrm{j}$

$\mathrm{n}_{\mathrm{h}} \quad$ Jumlah part yang diminta pada tiap interval $\mathrm{h}$

$\mathrm{N}_{\mathrm{h}} \quad$ Jumlah batch untuk setiap interval waktu Hh pada kasus multi due date

$\mathrm{Q}_{\mathrm{h}[\mathrm{i}]}$ Ukuran batch (unit) pada posisi ke-i pada interval waktu $\mathrm{H}_{\mathrm{h}}$

$\mathrm{Q}_{\mathrm{h}[\mathrm{j}]}$ Ukuran batch (unit) pada posisi ke-j pada interval waktu $\mathrm{H}_{\mathrm{h}}$

r Jumlah due date

s $\quad$ Waktu set up batch processor

$\mathrm{t} \quad$ waktu proses untuk setiap part

$\mathrm{s}_{\mathrm{i}} \quad$ Waktu set up batch processor pada posisi ke - $\mathrm{i}$

$\mathrm{s}_{\mathrm{j}} \quad$ Waktu set up batch processor pada posisi ke $-\mathrm{j}$

$\mathrm{W}_{\mathrm{h}} \quad$ Jumlah part yang dapat dikerjakan pada interval waktu $\mathrm{d}_{\mathrm{h}}$ yang bukan $\mathrm{H}_{\mathrm{h}}$ (multi due date) 
Asumsi yang digunakan:

- Permasalahan yang diselesaikan adalah penjadwalan untuk single item multi due date yang diproses pada batch processor tunggal.

- Waktu untuk memasang tools diasumsikan sama untuk setiap part

- Waktu set up untuk setiap batch diasumsikan konstan (tidak terpengaruh oleh urutan pemrosesan batch dan jumlah part yang terdapat pada satu batch)

- Waktu untuk memproses setiap part diasumsikan konstan

- Ukuran dari setiap batch yang dihasilkan dinyatakan dalam bilangan real positif

- Jumlah batch yang dihasilkan untuk setiap interval waktu (periode) adalah integer

- Penjadwalan batch dilakukan dengan pendekatan backward scheduling.

Berdasarkan asumsi dan notasi yang sudah ditetapkan, maka masalah pada penelitian ini dirumuskan sebagai berikut:

Minimasi:

$\mathrm{F}^{\mathrm{a}}=\left[\sum_{\mathrm{h}=1}^{\mathrm{r}}\left[\sum_{\mathrm{i}=1}^{\mathrm{N}_{\mathrm{h}}}\left\{\sum_{j=1}^{\mathrm{i}}\left(\left(\mathrm{t}+\mathrm{aQ}_{\mathrm{h}[\mathrm{i}]}\right)+\mathrm{s}_{j}\right)-\mathrm{s}_{\mathrm{i}}\right\} \mathrm{Q}_{\mathrm{h}[\mathrm{i}]}\right]\right]+$

$\left[\sum_{b=1}^{\gamma-1}\left\{\Sigma_{h=b+1}^{r}\left(D_{h}-n_{h}\right)\right\}\left(d_{b}-d_{b+1}\right)\right]$

Pembatas :

$\left(\mathrm{N}_{\mathrm{h}}-1\right) \mathrm{s}+\mathrm{t} \mathrm{N}_{\mathrm{h}}+\mathrm{a} \sum_{\mathrm{i}=1}^{\mathrm{N}_{\mathrm{h}}} \mathrm{Q}_{\mathrm{h}}[\mathrm{i}] \leq \mathrm{H}_{\mathrm{h}}, \mathrm{h}=1, \ldots, \mathrm{r}$

$\sum_{h=b+1}\left(D_{h}-n_{h}\right) \geq 0, \quad \mathrm{~b}=1, \ldots, \quad(\mathrm{r}-1)$

$\sum_{h=1}^{K} D_{h}-n_{h}=0$

$\sum_{i=1}^{N_{h}} Q_{k[i] 1}=D_{k}$,

$B_{h[1]}+a Q_{h[1]}+t=d_{h k}$, $\mathrm{h}=1, \ldots, \mathrm{r}(11)$

$Q_{h[1]}, D_{h} \geq 0, N_{h} \geq 1, i=1, \ldots, N_{h h} ; h=1_{s, \ldots} r$

Persamaan (7) menunjukkan bahwa pada setiap periode penjadwalan $\mathrm{H}_{\mathrm{h}}$, seluruh part $\mathrm{D}_{\mathrm{h}}$ harus diproses pada interval waktu produksi $\mathrm{H}_{\mathrm{h}}$, yang merupakan selisih dari $\left(\mathrm{d}_{\mathrm{b}}-\mathrm{d}_{\mathrm{b}+1}\right)$. Persamaan (8) menunjukkan bahwa jumlah seluruh part yang diproduksi dalam interval $\mathrm{H}_{\mathrm{h}}$ sampai $\mathrm{H}_{\mathrm{r}}$ minimal sama atau harus lebih besar dibandingkan dengan total jumlah part yang diminta pada interval waktu tersebut. Persamaan (9) menunjukkan bahwa total jumlah part yang diproses dalam periode penjadwalan harus sama dengan total jumlah part yang diminta pada periode penjadwalan. Persamaan (10) menunjukkan adanya keseimbangan material dalam tiap periode $\mathrm{H}_{\mathrm{h}}$. Persamaan (11) menunjukkan bahwa saat selesai pemrosesan batch ke satu pada setiap periode penjadwalan $\mathrm{H}_{\mathrm{h}}$ harus sama dengan due date dari periode tersebut sehingga hal ini menjamin tidak akan terjadi keterlambatan pengiriman. Persamaan (12) menunjukkan bahwa ukuran batch pada setiap interval waktu, jumlah permintaan pada setiap interval waktu harus lebih besar atau sama dengan nol, dan jumlah batch untuk setiap interval waktu harus lebih besar atau sama dengan satu.
Sub Algoritma 1.1

Langkah 1 Gunakan algoritma yang diusulkan pada [8]

Batch $\mathrm{n}_{\mathrm{h}}{ }^{*}$ dengan dummy due date $\mathrm{H}_{\mathrm{h}}$ yang nilainya adalah $\left(\mathrm{d}_{\mathrm{h}}-\mathrm{d}_{\mathrm{h}+1}\right) \cdot \mathrm{n}_{\mathrm{h}}{ }^{*}$ merupakan jumlah part yang akan dijadwalkan. Untuk $\mathrm{h}$ $=1$, maka na $_{\mathrm{h}}{ }^{*}=\mathrm{n}_{1}$. Jika $\left(N_{k}-1\right) s+N_{k} t+$ $\mathrm{an}_{\mathrm{h}}{ }^{*} \leq \mathrm{H}_{\mathrm{h}}$, set $\mathrm{D}_{\mathrm{h}}=\mathrm{n}_{\mathrm{h}}{ }^{*}$, dan lanjutkan ke langkah 3. Jika lainya,, lanjutkan ke langkah 2.

Langkah 2 Dengan menggunakan due date $\mathrm{d}_{\mathrm{h}}$ yang bukan $\mathrm{H}_{\mathrm{h}}$, gunakan algoritma yang diusulkan pada [8], batch $\mathrm{n}_{\mathrm{h}}{ }^{*}$, dan jadwalkan batch yang dihasilkan pada periode waktu untuk mendapatkan $\mathrm{W}_{\mathrm{h}}$ yang merupakan jumlah part yang akan diproses pada rentang $\mathrm{H}_{\mathrm{h}}$. Gunakan algoritma pada [8], batch kembali $\mathrm{W}_{\mathrm{h}}$ dengan interval waktu $\mathrm{H}_{\mathrm{h}}$, dan jadwalkan batch yang dihasilkan dengan waktu yang tersedia. Jika pada jadwal yang dihasilkan tidak terdapat idle time $\omega$, set $\mathrm{D}_{\mathrm{h}}=\mathrm{W}_{\mathrm{h}}$ dan lanjutkan ke langkah 3. Jika terdapat idle time, dan idle time $\geq(\mathrm{t}+\mathrm{a})$ maka tetapkan $D_{h}=W_{h}+\frac{\omega-t}{a}$ Lanjutkan ke langkah 3 .

Langkah 3. Definisikan $D_{h}$ sebagai jumlah part yang akan diproses pada mesin dengan periode $\mathrm{H}_{\mathrm{h}}$

Algoritma 1.1
Langkah 0.
langkah 1.
Langkah 1.
Langkah 2.

Inisialisasi parameter masalah. Lanjutkan ke

Set $\mathrm{h}=1$. Lanjutkan ke langkah 2.

Gunakan Sub algoritma 1.1, definisikan $\mathrm{D}_{\mathrm{h}}$. Lanjutkan ke langkah 3.

langkah 3. Set $\gamma_{h}=n_{h}{ }^{*}-D_{h} . \quad \gamma_{h}$ menyatakan jumlah part yang belum dijadwalkan pada periode $\mathrm{H}_{\mathrm{h}}\left(\right.$ untuk $\left.\gamma_{0}=0\right)$. Definisikan jumlah part yang dijadwalkan di periode $\mathrm{H}_{\mathrm{h}+1}$, gunakan $\mathrm{n}_{\mathrm{h}+1}{ }^{*}=\mathrm{n}_{\mathrm{h}+1}+\gamma_{\mathrm{h}}$. Set $\mathrm{h}=\mathrm{h}+1$. Jika $\mathrm{h} \leq \mathrm{r}$ kemudian lanjutkan ke langkah 2. Jika yang lainya lanjutkan ke langkah 4

Langkah 4. Gunakan algorima pada [8], batch kan $\mathrm{D}_{\mathrm{h}}$ dengan $\mathrm{H}_{\mathrm{h}}$ dan kemudian jadwalkan batch yang dihasilkan pada jadwal yang terakhir. Berdasarkan hal ini, hitung total waktu tinggal aktual dari seluruh part pada lantai produksi menggunakan persamaaan (6).

\section{HASIL DAN ANALISIS}

Model yang dihasilkan pada penelitian ini diuji dengan menggunakan data hipotetik. Data hipotetik yang digunakan disusun dalam tiga skenario berikut:

Skenario 1 disusun dengan menggunakan data permintaan part single item sejumlah $\mathrm{n}_{1}, \mathrm{n}_{2}, \mathrm{n}_{3}, \mathrm{n}_{4}$ dengan due date $\mathrm{d}_{1}, \mathrm{~d}_{2}$, $\mathrm{d}_{3}, \mathrm{~d}_{4}$. Ketentuan pada skenario 1 adalah seluruh permintaan 
part pada setiap periode permintaan dapat dikerjakan pada periode sesuai dengan periode saat part tersebut diminta. Waktu set up mesin adalah s, waktu untuk memproses satu part adalah t, dan waktu memasang tools untuk setiap part adalah a.

Tabel 1

Set data dan hasil perhitungan total waktu tinggal aktual untuk skenario 1

\begin{tabular}{|c|c|c|c|c|c|c|c|c|}
\hline $\mathrm{n}_{\mathrm{h}}$ & $\mathrm{d}_{\mathrm{h}}$ & $\mathrm{t}$ & \begin{tabular}{|l|l}
$\mathrm{s}$ & $\mathrm{a}$ \\
\end{tabular} & & $\mathrm{N}_{\mathrm{h}}$ & $\mathrm{Q}_{\mathrm{h}[\mathrm{i}]}$ & $\mathrm{B}_{\mathrm{h}[i]}$ & $\mathrm{F}^{\mathrm{a}}$ \\
\hline $\begin{array}{l}\mathrm{n}_{1}=200, \\
\mathrm{n}_{2}=180, \\
\mathrm{n}_{3}=175, \\
\mathrm{n}_{4}=200\end{array}$ & $\begin{array}{l}\mathrm{d}_{1}=1200, \\
\mathrm{~d}_{2}=900, \\
\mathrm{~d}_{3}=650, \\
\mathrm{~d}_{4}=400\end{array}$ & 30 & \begin{tabular}{|l|l}
5 & 1 \\
\end{tabular} & 1 & $\begin{array}{l}\mathrm{N}_{1}=2 \\
\mathrm{~N}_{2}=2 \\
\mathrm{~N}_{3}=2 \\
\mathrm{~N}_{4}=3\end{array}$ & $\begin{array}{l}\mathrm{Q}_{1[1]}=117,5, \\
\mathrm{Q}_{1[2]}=82,5 \\
\mathrm{Q}_{2[1]}=107,5, \\
\mathrm{Q}_{2[2]}=72,5 \\
\mathrm{Q}_{3[1]}=105, \mathrm{Q}_{3[2]} \\
=70 \\
\mathrm{Q}_{4[1]}=101,67, \\
\mathrm{Q}_{4[2]}=66,67, \\
\mathrm{Q}_{4[3]}=31,66\end{array}$ & $\begin{array}{l}\mathrm{B}_{1[1]}=1052,5, \\
\mathrm{~B}_{1[2]}=935 \\
\mathrm{~B}_{2[1]}=762,5, \\
\mathrm{~B}_{2[2]}=655 \\
\mathrm{~B}_{3[1]}=515, \mathrm{~B}_{3[2]} \\
=410 \\
\mathrm{~B}_{4[1]}=268,33, \\
\mathrm{~B}_{4[2]}=166,66, \\
\mathrm{~B}_{4[3]}=100\end{array}$ & $\begin{array}{l}141.154 \\
2\end{array}$ \\
\hline \begin{tabular}{|l|} 
Total $=755$ \\
\end{tabular} & & & & & & Total $=755$ & & \\
\hline
\end{tabular}

Pada tabel 1 dapat dilihat bahwa total part yang diminta setiap periode sama dengan total part yang diproses di setiap periode dan total part yang diminta untuk seluruh periode sama dengan total part yang diproses untuk seluruh periode. Hal ini menunjukkan bahwa seluruh permintaan part pada setiap periode dapat diproses pada periode sesuai dengan periode part tersebut diminta. Tidak terdapat part yang dikerjakan pada periode setelah periode permintaan part. Pada skenario 1 ini diperoleh jadwal yang layak dengan waktu mulai pemrosesan batch pada saat $\mathrm{t}=31,66$ dengan total waktu tinggal aktual adalah 141.154,2 menit.

Skenario 2 disusun dengan menggunakan data permintaan part single item sejumlah $\mathrm{n}_{1}, \mathrm{n}_{2}, \mathrm{n}_{3}, \mathrm{n}_{4}$ dengan due date $\mathrm{d}_{1}, \mathrm{~d}_{2}$, $\mathrm{d}_{3}, \mathrm{~d}_{4}$. Ketentuan pada skenario 2 adalah tidak seluruh permintaan part pada setiap periode dapat dikerjakan pada interval waktu sesuai dengan waktu saat part tersebut diminta. Part yang tidak dapat dikerjakan pada periode part tersebut diminta akan dikerjakan pada periode setelahnya. Waktu set up mesin adalah $\mathrm{s}$, waktu untuk memproses satu part adalah $\mathrm{t}$, dan waktu memasang tools untuk setiap part adalah a.

Tabel 2

Set data dan hasil perhitungan total waktu tinggal aktual untuk skenario 2

\begin{tabular}{|l|l|l|l|l|l|l|l|l|}
\hline $\mathrm{n}_{\mathrm{h}}$ & $\mathrm{d}_{\mathrm{h}}$ & $\mathrm{t}$ & $\mathrm{s}$ & $\mathrm{a}$ & $\mathrm{N}_{\mathrm{h}}$ & $\mathrm{Q}_{\mathrm{h}[1]}$ & $\mathrm{B}_{\mathrm{h}[1]}$ & $\mathrm{F}^{\mathrm{a}}$ \\
\hline $\mathrm{n}_{1}=250$, & $\mathrm{d}_{1}=1200$, & 30 & 5 & 1 & $\mathrm{~N}_{\mathrm{l}}=1$ & $\mathrm{Q}_{1[1]}=250$ & $\mathrm{~B}_{[[1]}=920$ & $310.941,9$ \\
$\mathrm{n}_{2}=220$, & $\mathrm{d}_{2}=900$, & & & & $\mathrm{N}_{2}=2$ & $\mathrm{Q}_{2[1]}=107,5$, & $\mathrm{B}_{2[1]}=762,5$, & \\
$\mathrm{n}_{3}=240$, & $\mathrm{d}_{3}=650$, & & & $\mathrm{N}_{3}=3$ & $\mathrm{Q}_{2[2]}=72,5$ & $\mathrm{~B}_{2[2]}=655$ & \\
$\mathrm{n}_{4}=205$ & $\mathrm{~d}_{4}=400$ & & & $\mathrm{~N}_{4}=1$ & $\mathrm{Q}_{3[1]}=75,83$, & $\mathrm{B}_{3[1]}=544,17$, & \\
& & & & & & $\mathrm{Q}_{3[2]}=40,83$, & $\mathrm{B}_{3[2]}=468,34$, & \\
& & & & & $\mathrm{Q}_{3[3]}=5,83$ & $\mathrm{~B}_{3[3]}=427,51$ & \\
& & & & & $\mathrm{Q}_{4[1]}=362,5$ & $\mathrm{~B}_{4[1]}=2,5$ & \\
& & & & & $\mathrm{n}_{23}=40, \mathrm{n}_{34}$ & & \\
& & & & & & & \\
& & & & & & & & \\
\hline Total=915,51 & & & \\
\hline
\end{tabular}

Pada tabel 2 dapat dilihat bahwa total part yang diminta setiap periode tidak sama dengan total part yang diproses setiap periode, seperti pada interval waktu ke empat. Jumlah permintaan pada periode 4 adalah 205, namun jumlah part yang dikerjakan pada interval waktu tersebut sejumlah 485 part. Hal ini menunjukkan bahwa terdapat sejumlah part yang diminta pada periode sebelumnya namun waktu yang tersedia pada periode sebelumnya tidak cukup untuk melakukan pemrosesan part, sehingga part diproses pada periode setelahnya. Namun, jika dilihat pada total part yang diminta untuk seluruh periode sama dengan total part yang diproses untuk seluruh periode. Hal ini menunjukkan bahwa meskipun terdapat part yang dikerjakan tidak sesuai dengan periode permintaan part, seluruh permintaan part tetap dapat diproses dan diperoleh jadwal yang layak dengan waktu mulai pemrosesan batch pada saat $\mathrm{t}=2,5$ dengan total waktu tinggal aktual adala $310.941,9$ menit.

Skenario 3 disusun dengan menggunakan data permintaan part single item sejumlah $\mathrm{n}_{1}, \mathrm{n}_{2}, \mathrm{n}_{3}, \mathrm{n}_{4}$ dengan due date $\mathrm{d}_{1}, \mathrm{~d}_{2}$, $\mathrm{d}_{3}, \mathrm{~d}_{4}$. Ketentuan pada skenario 3 adalah tidak seluruh permintaan part dapat dikerjakan pada periode sesuai dengan waktu saat part tersebut diminta. Part yang tidak dapat dikerjakan pada interval waktu dimana part tersebut diminta dikerjakan pada periode setelahnya, namun waktu yang tersedia tidak mencukupi untuk mengerjakan permintaan part. Waktu set up mesin adalah s, waktu untuk memproses satu part adalah $\mathrm{t}$, dan waktu memasang tools untuk setiap part adalah a.

Tabel 3

Set data dan hasil perhitungan total waktu tinggal aktual untuk skenario 3

\begin{tabular}{|c|c|c|c|c|c|c|c|c|}
\hline $\mathrm{n}_{\mathrm{h}}$ & $d_{h}$ & $t$ & \begin{tabular}{|l|}
$s$ \\
\end{tabular} & \begin{tabular}{|l|}
$a$ \\
\end{tabular} & $\mathrm{~N}_{\mathrm{h}}$ & $\mathrm{Q}_{\mathrm{h}[i]}$ & $\mathrm{B}_{\mathrm{h}[\mathrm{i}]}$ & $\mathrm{F}$ \\
\hline $\begin{array}{l}\mathrm{n}_{1}=275, \\
\mathrm{n}_{2}=250, \\
\mathrm{n}_{3}=260, \\
\mathrm{n}_{4}=210\end{array}$ & $\begin{array}{l}\mathrm{d}_{1}=1200, \\
\mathrm{~d}_{2}=900, \\
\mathrm{~d}_{3}=650, \\
\mathrm{~d}_{4}=400\end{array}$ & 30 & 5 & 1 & $\begin{array}{l}\mathrm{N}_{1}=2 \\
\mathrm{~N}_{2}=3 \\
\mathrm{~N}_{3}=2 \\
\mathrm{~N}_{4}=2\end{array}$ & $\begin{array}{l}\mathrm{Q}_{1[1]}=121,25 \\
\mathrm{Q}_{1[2]}=86,25 \\
\mathrm{Q}_{2[1]}=78,95, \\
\mathrm{Q}_{2[2]}=43,95, \\
\mathrm{Q}_{2[3]}=8,95 \\
\mathrm{Q}_{3[1]}=97,06, \\
\mathrm{Q}_{3[2]}=62,06 \\
\mathrm{Q}_{4[1]}=170, \\
\mathrm{Q}_{4[2]}=135 \\
\mathrm{n}_{12}=67,5, \mathrm{n}_{23} \\
=185,65, \mathrm{n}_{24}= \\
26,53, \mathrm{n}_{34}=260\end{array}$ & 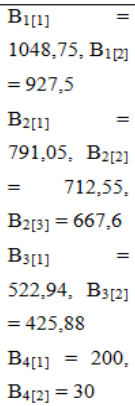 & - \\
\hline Total $=995$ & & & & & & Total $=802,07$ & & \\
\hline
\end{tabular}

Pada tabel 3 dapat dilihat bahwa total part yang diminta setiap periode tidak sama dengan total part yang diproses di setiap periode. Hal ini menunjukkan bahwa terdapat sejumlah part yang diminta pada periode sebelumnya namun waktu pada periode sebelumnya tidak cukup untuk melakukan pemrosesan part, sehingga part diproses pada periode setelahnya. Namun, jika dilihat pada jumlah seluruh part yang diminta untuk seluruh periode tidak sama dengan jumlah seluruh part yang diproses pada seluruh periode, sehingga jadwal yang dihasilkan adalah jadwal yang tidak layak karena untuk mengerjakan seluruh permintaan part pada seluruh periode akan melanggar saat $\mathrm{t}=0$. 


\section{KESIMPULAN}

Pada masalah single item multi due date, jumlah batch, ukuran batch, dan urutan pemrosesan batch untuk setiap interval waktu $\mathrm{H}_{h}$ diselesaikan dengan memandang satu interval waktu $\mathrm{H}_{\mathrm{h}}$ sebagai permasalahan common due date dan dijadwalkan secara backward. Berdasarkan perhitungan dan analisis yang dilakukan dengan data hipotetik dapat disimpulkan:

- $\quad$ Part yang diminta pada satu periode akan dikerjakan pada periode yang sama dengan periode permintaan part jika untuk setiap periode terpenuhi kondisi $\left(\mathrm{N}_{\mathrm{h}}-\right.$ 1) $\mathrm{s}+\mathrm{N}_{\mathrm{h}} \mathrm{t}+\mathrm{an}_{\mathrm{h}} * \mathrm{H}_{\mathrm{h}}$ dengan $\mathrm{H}_{\mathrm{h}}$ adalah dummy due date yang didalamnya sudah memperhitungkan waktu set up batch.

- $\quad$ Pada $\mathrm{h}<\mathrm{r}$ ( interval waktu sebelum interval waktu terakhir (r)) jika kondisi $\left(\mathrm{N}_{\mathrm{h}}-1\right) \mathrm{s}+\mathrm{N}_{\mathrm{h}} \mathrm{t}+\mathrm{an}_{\mathrm{h}^{*}} \leq \mathrm{H}_{\mathrm{h}}$ tidak selalu terpenuhi untuk setiap periode maka part dapat dikerjakan pada periode setelahnya $\left(\mathrm{H}_{\mathrm{h}+1}\right)$ dan akan dikirim sesuai dengan due date dari part tersebut.

- Jadwal akan layak jika pada saat $\mathrm{h}=\mathrm{r}$ (interval waktu terakhir) terpenuhi kondisi $\left(\mathrm{N}_{\mathrm{h}}-1\right) \mathrm{s}+\mathrm{N}_{\mathrm{h}} \mathrm{t}+\mathrm{an}_{\mathrm{h}^{*}} \leq$ $\mathrm{H}_{\mathrm{h}}$ dengan $\mathrm{n}_{\mathrm{h}}$ adalah jumlah part yang diminta pada periode terakhir ditambah dengan jumlah part yang tidak dapat diproses pada periode sebelumnya sebelumnya (jika ada).

- Total waktu tinggal aktual akan semakin besar jika terdapat part yang diproses pada periode yang tidak sesuai dengan periode permintaan part tersebut.

\section{DAFTAR PUSTAKA}

[1] Sukoyo., Samadhi, TMA.A., Iskandar, BP., Halim, A.H,"Model Penjadwalan Batch Multi Item dengan Dependent Processing Time", Jurnal Teknik Industri, Vol 12 no.2, 69-80. Desember, 2010.

[2] Potts, C N., Kovalyov, M.Y.,'Scheduling with Batching: a Review", European Journal of Operational Research, 120, 228-249. 2001.

[3] Mahtirajan, M., Sivakumar, A.I,"a literatur review, Classification and Simple Meta Heuristic on Scheduling of Batch processors in Semiconductor",International Journal Advance Manufacturing Technology, 29, 990 - 1001 January, 2006

[4] Hidayat, Nita P.A.,Cakravastia, A., Samadhi, TMA.A,"A Single item Batch Scheduling Model on a Batch processor to Minimize Total actual Flow time of Parts Through The Shop",Proceedings of Asia Pasific Industrial Engineering \& Management System Conference (APIEMS).

[5] Halim, A.H,"Batch Scheduling for Production Under Just In Time Environment", Dissertation, University of Osaka Prefectur, 1993.

[6] Dobson, Greogory., Nambimadom, Ramakrishnan S, "The Batch Loading and Scheduling Problem. Operation
Reseach,",Operations Research. Vol 49 no.1, pp 52 - 56. (Januari - Februari ), 2001.

[7] Sukoyo., Samadhi, TMA Ari., Iskandar, Bermawi P., Halim, Abdul Hakim,"Batch scheduling for a single machine processing parts of a single item with increasing processing time to minimize total actual flow time", Proceedings of the 9th Asia Pasific Industrial Engineering \& Management Systems Conference. December, 2008.

[8] Astuti, M.D., Halim,A.H, "Model Penjadwalan Batch pada Batch Processor dengan Waktu Proses yang Tidak Konstan", Prosiding Seminar nasional BKSTI pp II175.September, 2014.

[9] Halim, A.H., Miyazaki, S., and Ohta, H,"Batchscheduling Problems to Minimize Actual Flow times of Parts Through the Shop under JIT Environment", European Journal of Operational Research, 72, 529-544. 1994. 